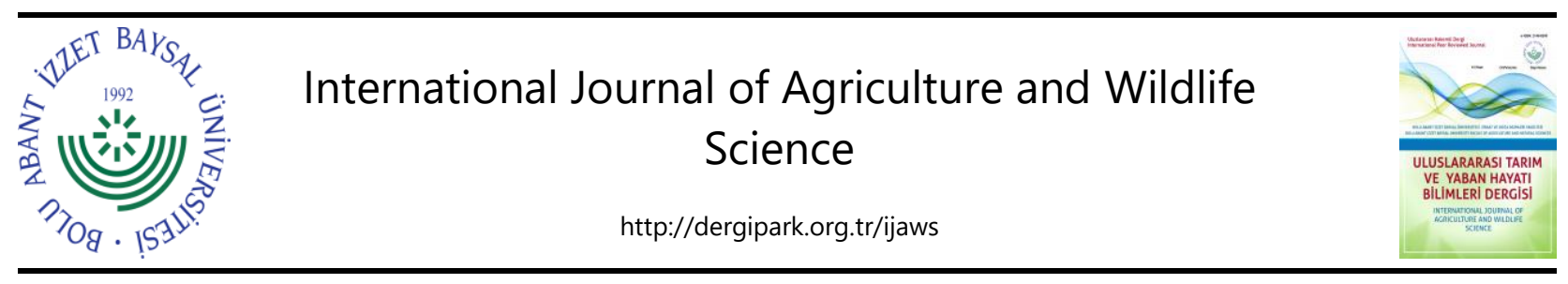

Research Article

\title{
Efficacy of Anti-Transpirant Sprays on Fruit Cracking and on Fruit Quality at Harvest and Post-Harvest Storage in Sweet Cherry
}

\author{
Penny Measham 1 , Lynn Edwards Long ${ }^{3}$, Erdal Aglar ${ }^{2 *}$ Clive Kaiser ${ }^{3}$ \\ ${ }^{1}$ Tasmanian Institute of Agriculture, University of Tasmania, Australia \\ 2 Sivas Cumhuriyet University, Suşehri Timur Karabal Vocational School, Sivas, Turkey \\ ${ }^{3}$ Oregon State University Extension, The Dalles, United State
}

Received: 21.02.2020 Accepted: 08.05.2020

\begin{abstract}
Keywords:
Parka, Sureseal, Prunus avium, cracking, fruit firmness
\end{abstract}

*Corresponding author erdalaglar@hotmail.com
Abstract. This study was designed to confirm the efficacy of anti-transpirant sprays on reducing fruit cracking in cherry, and to evaluate the impact on fruit quality at harvest and during post-harvest storage. In the study, it was observed that there were differences in the rate of natural cracking depending on the amount of precipitation, but there were inconsistencies in the differences. In some trials, the amount of precipitation has no effect on the rate of cracking, but generally the increase in the amount of precipitation has increased the rate of cracking. It has been determined that there is a significant reduction in cracking rate due to spray applications. Sprays consistently had minimal effect on fruit quality overall. Assessments of fruit post-harvest highlighted that all fruit, treated and untreated, exhibited similar behaviour during storage.

\section{Kirazda Hasatta ve Hasat Sonrası Depolamada Meyve Çatlaması ve Meyve Kalitesi Üzerine Anti-Transpirant Sprey Uygulamalarının Etkisi}

\begin{tabular}{ll}
\hline Anahtar kelimeler: & Özet. Bu çalışma, anti-transpirant spreylerin kirazlarda meyve çatlamasını azaltma üzerindeki \\
Parka, Sureseal, Prunus avium, & etkinliğini doğrulamak ve hasatta ve hasat sonrası depolama sırasında meyve kalitesi \\
çatlama, meyve eti sertliği & üzerindeki etkisini değerlendirmek için yürütülmüştür. Çalışmada, yağış miktarına bağlı olarak \\
& doğal çatlama oranında farklılıkların meydana geldiği, ancak oluşan farklılıklarda tutarsızlıkların \\
& olduğu görüldü. Bazı denemelerde yağış miktarının çatlama oranı üzerine etkisinin olmadığı, \\
& ancak genellikle yağış miktarının artırması çatlama oranını artırmıştır. Sprey uygulamalarına \\
& bağlı olarak çatlama oranında önemli azalmalar olduğu belirlenmiştir. Spreylerin genel olarak \\
& meyve kalitesi üzerinde etkisi minimum olmuştur. Hasat sonrası yapılan ölçüm ve analizlerde \\
& sprey uygulaması ve kontrol uygulamasına ait meyvelerin depolama sırasında benzer davranış \\
& sergiledikleri belirlenmiştir.
\end{tabular}




\section{INTRODUCTION}

The production of sweet cherry fruit is intensive and high-risk. A major challenge throughout the growing period is rain-induced fruit cracking, and the unpredictable nature of summer rainfalls that have the potential to reduce both yield and quality (Simon, 2006; Measham et al., 2009; Kaiser et al., 2014). Technologies to mitigate rain damage, such as rain covers, are costly (Simon, 2006) but there are in field strategies showing promise (Measham et al., 2009; Kaiser et al., 2014). While less expensive, these strategies must not only improve marketable yield of fruit but also not induce any negative impacts during post-harvest storage and transport. Sweet cherry fruit are a thin-skinned, soft fruit and the major challenge post-harvest is maintaining quality for greater than a few weeks (Mozetic et al., 2006). Many studies (Clayton et al., 2003; Sekse, 2008; Liu et al., 2013) highlight the need to achieve high quality fruit at harvest, and improve post-harvest quality, extend storage periods and improve market flexibility but few studies focus on pre-harvest treatments that also show benefits post-harvest. Fruit harvested and then arriving at retail destinations (domestic or export) must be good quality; it has been reported that losses of $12 \%$ at the retail level can occur due to low quality fruit (Clayton et al., 2003) Maintaining fruit quality starts with producing optimum fruit at harvest. Prevention of rain-induced fruit cracking during the growing season has a long history of investigating different spray applications with inconsistent results. Long et al. (2009) suggest that some of the inconsistency associated with sprays is the inconsistent level of wax components in fruit skin, and it has been established that no new cuticle formation occurs in the later stages of fruit growth (Knoche et al., 2001) but becomes thin and under stress as fruit enlarges allowing for increased skin conductance to water (Knoche and Peschel, 2001; Knoche et al., 2004). Additionally, fruit can develop microscopic cuticular fractures during the last two weeks of their growth period (Hovland and Sekse, 2004) further reducing the natural barrier to water uptake (Alkio, 2012). It is this loss of integrity that is thought to promote the visible cracking that is associated with rainfall. Measham et al. (2010) suggested that inconsistency can also be associated with crack types not being differentiated in studies. The assumptions underlying the use of sprays is to prevent uptake of water across the fruit skin, by either providing an artificial covering on the fruit to improve integrity of the fruit surface or changing the osmolarity of the fruit surface (Sekse, 1995). Anti-transpirants, such as Bioguard ${ }^{\circledR}$ (a calcium based product), and Vapor Gard $®$ (a terpene polymer providing a protective film) have been trialled in relation to fruit cracking, on the premise that they will limit water uptake, as well as loss, from the fruit (Hanson and Proebsting, 1996). Anti-transpirants are commonly used to reduce plant water stress however they have also been shown to negatively impact on the levels of soluble solids because they limit gaseous exchange (Webster and Cline, 1994). Bioguard ${ }^{\circledR}$ reduced cracking by $52 \%$ in variety 'Van' in trials in South America (Torres et al., 2009). Recent investigations of a new copolymer of stearic acid, cellulose and calcium (SureSeal) and a related product by the same developers with palm oil replacing the stearic acid (Parka $\left.{ }^{\circledR}\right)$, has shown that anti-transpirants may have considrerable potential. A preliminary trial in Norway resulted in a $15 \%$ reduction of cracked fruit with the application of SureSeal in conjunction with rain covers while further trials testing rate of application showed a reduction of up to $250 \%$ cracking and an increase both soluble solids and fruit pedicel retention force, but some reduction in firmness (Kaiser et al., 2014).

Cherries decay rapidly post-harvest (Mozetic et al., 2006) and the inability to extend storage times has economic implications (Liu et al., 2013) especially for countries exporting to counter-seasonal markets. Cold storage is common for much horticultural produce (Clayton et al., 2003; Hu et al., 2011) and cherries are no exception with typical storage temperatures varying between $0^{\circ} \mathrm{C}$ and $5^{\circ} \mathrm{C}$ (Ikediala et al., 2002; Mozetic et al., 2006; Puniran et al., 2012). Cooler temperatures, high humidity and modified atmosphere packing are all in use for cherry post-harvest storage and will reduce the rate of respiration and subsequent loss of water and sugars (Wang and Long, 2014). In cherries the rate of respiration has been shown to differ with varieties (Wang and Long, 2014). However, cherry fruit degradation may still occur due to high skin conductance to water. During storage cuticle integrity will impact on water loss and rate of degradation. Waxy coatings have shown to retard water loss and increase firmness of pineapples ( $\mathrm{Hu}$ et al., 2011) and are a common technique to delay degradation in a number of fruit and vegetable products. To date, applying coatings on cherries post-harvest is difficult given the delicate nature of the fruit however applying coatings pre-harvest could be used.

Consequently, these current studies were designed to comprehensively investigate the effects of application of a novel cracking-prevention spray on sweet cherry fruit quality at harvest, but also on quality after postharvest storage. In this way, a level of confidence in the use of this management strategy for fruit cracking can be determined. The study further aimed to confirm the efficacy of the spray to increase yield through the reduction of cracking. 


\section{MATERIALS AND METHODS}

\section{Plant Material and Trial Sites}

Trials were undertaken in both northern and southern hemisphere cherry producing regions; see Table 1 for trial year, location, region and cherry variety. Mature cherry trees of several variety, rootstock and training system combinations were used; based on the common combination for each region. Those combinations included 'Stella, 'Simone' and 'Sweetheart' on F12/1 rootstock trained to a Kym Green Bush system; 'Skeena'/Gi 6/multi-leader bush, 0900 Ziraat/Gi 6; tall spindle axe and 'Early Burlat'/Mazzard/multi-leader bush. All trial trees were managed under commercial practices common to the region and were representative of commercial production.

Table 1. Trial details.

Çizelge 1. Deneme detayları.

\begin{tabular}{llllllll}
\hline Trial & Country & Region & Location & Variety & Harvest & $\begin{array}{l}\text { Rainfall } \\
(\mathbf{m m})\end{array}$ & $\begin{array}{l}\text { Yield } \\
(\mathbf{t ~ h a )}\end{array}$ \\
\hline 1 & Australia & South Aust & Lenswood & Stella & $01 / 01 / 11$ & 18.8 & 16.1 \\
2 & Australia & South Aust & Lenswood & Simone & $14 / 01 / 11$ & 17.0 & 15.4 \\
3 & Australia & Tasmania & Huonville & Sweetheart & $25 / 01 / 11$ & 58.2 & 12.4 \\
4 & Australia & Tasmania & Old Beach & Sweetheart & $03 / 02 / 11$ & 49.4 & 9.8 \\
5 & Australia & Tasmania & Huonville & Sweetheart & $01 / 02 / 12$ & 53.6 & 10.6 \\
6 & USA & Oregon & The Dalles & Skeena & $07 / 03 / 13$ & 19.3 & 8.4 \\
7 & USA & Oregon & Dufur & Skeena & $07 / 12 / 13$ & 11.7 & 5.4 \\
8 & Turkey & Manisa & Turgutlu & 0900 Ziraat & $09 / 06 / 14$ & 29.6 & 2.0 \\
9 & Turkey & Aydin & Söke & 0900 Ziraat & $10 / 06 / 14$ & 77.6 & 9.7 \\
10 & Turkey & Uşak & Eşme & Early Burlat & NA & 85.8 & NA \\
\hline
\end{tabular}

\section{Climate}

In the southern hemisphere regions in Trials 1-5 climate data were accessed from the nearest Bureau of Meteorology weather station (within $5 \mathrm{~km}$ from trial sites) with the total amount of rainfall recorded for each site during the three-week period prior to harvest. Weather data for Trials 6-10 were obtained from grower owned weather stations located in the orchard, or in the case of Trial 6, within $2 \mathrm{~km}$ of the trial.

\section{Trial Designs}

Trials 1, 2, 3, 4 and 5 were undertaken in a randomised complete block design, with five replicates of eight tree plots. Each plot was isolated from other trees by four buffer trees within rows, and two rows within the block. After harvest, a full block was abandoned in each of trials 3 and 5 due to issues beyond the control of the experiment (pickers moving in early and irrigation failure respectively) leaving 4 replicates for analysis.

Trials 6 and 7 were undertaken in a randomized complete block design, with six replicates of four tree plots. Each plot was isolated from other trees by four buffer trees within rows, and one row within the block.

Trials 8 through 10 were undertaken in a randomized complete block design, with six replications of twentyfive trees per plot. Each replication was isolated from others by a buffer row.

Treatments for all trials included spray applications of SureSeal (SS) or Parka (P) and a no-spray control. Spray applications for trials 1-5 used SS, trials 6 and 7 used both SS and P at different application timings to assess any difference both between products and time of application. Timings included immediately after shuck fall (T1), straw colour (T2), 10 days after straw colour (T3) and straw colour plus 10 days after straw colour (T4). Spray applications for all other trials were applied according to the manufacturers' instructions (equivalent to T4) based on previous studies (Kaiser et al. 2014). All spray applications were made using commercial hydraulic airblast sprayers.

\section{Fruit Assessments-Harvest and Post-Harvest}

In the study, harvest maturity (in line with commercial harvest) subsamples were collected for quality analysis. For trials $1-5$ and trials $6-10$ at least $2 \mathrm{~kg}$ and $1 \mathrm{~kg}$ fruit respectively were harvested from each trial tree in each plot and transported immediately for assessment of cracking and quality parameters. Cracking was recorded as a percentage of total fruit for each plot. Additionally, in trials 1-5 cracks were differentiated into side-cracked, end-cracked (apical and stem-end) and non-cracked fruit given previous studies highlighting the different mode of water uptake responsible for each crack type (Measham et al., 2010). A subsample of 25 nonblemished fruit from each tree in each plot was assessed for quality at the time of harvest with means for plots 
used for analysis. A further subsample of 25 fruit was stored for two weeks at between $0-2^{\circ} \mathrm{C}$ and assessed as per fruit at harvest.

In all trials were: total soluble solids (recorded in brix using an Atago digital refractometer), size (recorded in $\mathrm{mm}$ at the widest point of the fruit using digital calipers), and firmness (recorded in $\mathrm{mm} \mathrm{g}^{-1}$ using a Bioworks Firmtech 2 for Trials 1-7 and in N using a Zwick Z0.5 (Zwick/Roell Z0.5, Germany) for Trials 8-10). Titratable Acidity for trials 3-5 was also assessed (recorded in $\mathrm{g} L$ using an MEP Instruments Metrohm 702 Titrino autotitrator), In trials 5-7, pedicel-fruit retention force (FPRF) was recorded in $\mathrm{g}$ using either a stand mounted Mark 10 force gauge or a Shimpo FGV-5X force meter.

\section{Statistical Analysis}

Proc glm ANOVA (SPSS and SAS) was used to assess effect of spraying on cracking and quality parameters at harvest, and post-harvest. Two-way ANOVA was used to assess the impact of spray type and timing of application in Trials 6 and 7. Percentage data (cracking incidence) was transformed prior to analysis but means of raw data are presented in the results. Fisher's protected least significant difference was used to compare mean treatment effects (where there were no treatment interactions). Significance level was set as $\mathrm{P}<0.05$.

\section{RESULTS}

\section{Climate}

All trials received rainfall in the three-week period prior to harvest (Table 1). Prior to this no cracks were evident on visual inspection of all trial sites. It was observed that there were differences in the rate of natural cracking depending on the amount of precipitation, but there were inconsistencies in the differences. In some trials, the amount of precipitation has no effect on the rate of cracking, but generally the increase in the amount of precipitation has increased the rate of cracking. It has been determined that there is a significant reduction in cracking rate due to spray applications.

\section{Impact of Sprays on Cracking at Harvest}

Significant reductions in total cracking due to spray treatments were seen in each trial; significant reductions were seen in 9 of the 10 trials (all except trial 6). Total cracking incidence for trials 1-5 and 8-10 are presented in Table 2. In trial 2 the reduction in cracking incidence in the field at harvest was due to lower incidences of both end cracks and side cracks (Figure 1) but the reductions seen in trials 4 and 5 were due to significant decreases in the level of end-cracks (apical and stem-end), not side cracks (Figure 2). Furthermore, while there was lower incidence, but not a significant reduction, of total cracks in trials 1 and 3, there were significantly less end-cracks with spray applications. In trial 6, there was no significant interactions, or main effect of product or timing on cracking incidence, but trial 7 showed that while there was no interaction or difference between spray types (cracking incidence with SureSeal was reduced to $2 \%$, and with Parka (P) to $1.7 \%$ compared to $4.5 \%$ without any spray application), there was a significant impact of application at all application times compared to the control (Table 3). Trials 8 low levels of rainfall, 9 and 10 showed clear and significant reductions in total cracking after high levels of rainfall (Table 2).

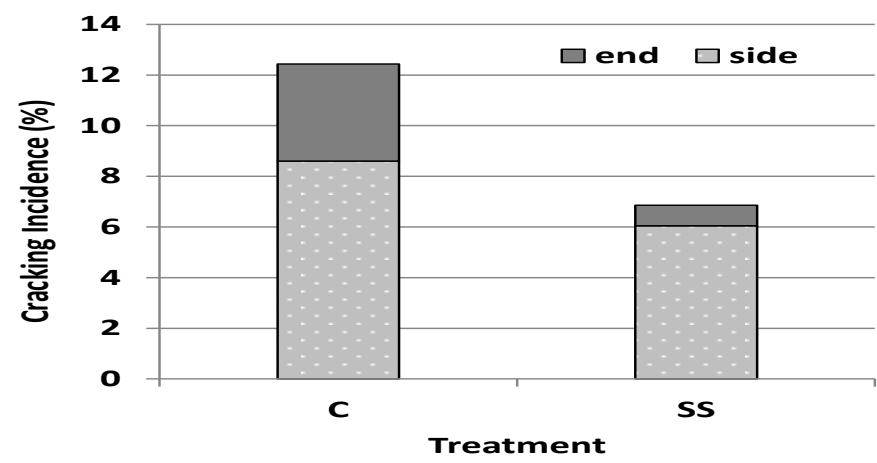

Figure 1. Total cracking incidence (\%) in treated (spray application) and untreated trees from trial 2.

Şekil 1. Deneme 2'den sprey uygulanmış ve uygulanmamış ağaçlarda toplam çatlama indeksi (\%).

A significant reduction was found in total, side and end-cracked fruit $(P \leq 0.01, P=0.04$ and $P \leq 0.01$ respectively). Raw data (percentage of incidence) provided in figure, but significance was determined by ANOVA using transformed data. 
Measham et al., The Efficacy of Anti-Transpirant Sprays on Fruit Cracking and on Fruit Quality at Harvest and Post-Harvest Storage in Sweet Cherry
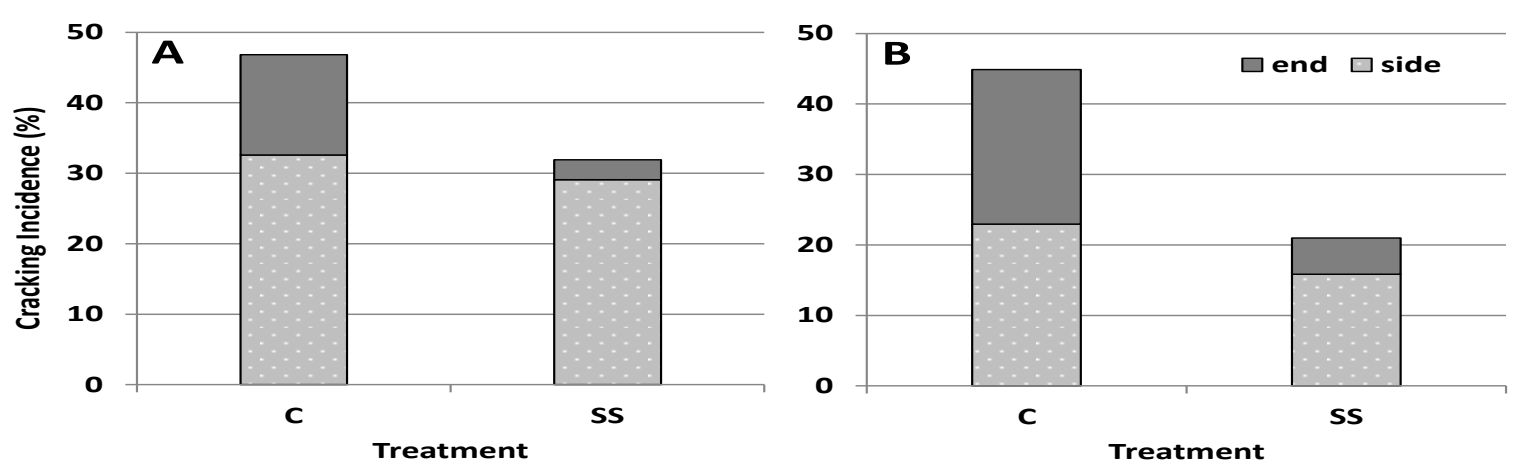

Figure 2. Total cracking incidence in treated (spray application) and untreated trees from trials $1,4(A)$ and 5 (B). Şekil 2. 1, 4 (A) ve 5 (B) denemelerinden sprey uygulanmış ve uygulanmamış ağaçlarda toplam çatlama indeksi. A significant reduction was found in total and end-cracked fruit in both trials. Significance was determined by ANOVA using transformed data. Raw data (percentage of incidence) provided in figure.

Table 2. Cracking incidence (\%) in treated spray applications of SureSeal (SS) or Parka (P) and untreated control (C) trees from trials $1-5$ and $8-10$.

Çizelge 2. 1-5 ve 8-10 denemelerinde SureSeal (SS) veya Parka (P) sprey uygulamaları ve kontrol (C) uygulamasına ait ağaçlarında çatlama indeksiı (\%).

\begin{tabular}{lcc}
\hline Trial & Treatment & Cracking (\%) \\
\hline 1 & $\mathrm{C}$ & $8.40 \mathrm{a}$ \\
& $\mathrm{SS}$ & $6.64 \mathrm{~b}$ \\
\hline 2 & $\mathrm{C}$ & $12.44 \mathrm{a}$ \\
& $\mathrm{SS}$ & $6.86 \mathrm{~b}$ \\
\hline 3 & $\mathrm{C}$ & $43.19 \mathrm{a}$ \\
& $\mathrm{SS}$ & $28.04 \mathrm{~b}$ \\
\hline 4 & $\mathrm{C}$ & $46.85 \mathrm{a}$ \\
& $\mathrm{SS}$ & $31.93 \mathrm{~b}$ \\
\hline 5 & $\mathrm{C}$ & $44.89 \mathrm{a}$ \\
& $\mathrm{SS}$ & $20.99 \mathrm{~b}$ \\
\hline 8 & $\mathrm{C}$ & $21.33 \mathrm{a}$ \\
& $\mathrm{P}$ & $12.00 \mathrm{~b}$ \\
\hline 9 & $\mathrm{C}$ & $31.33 \mathrm{a}$ \\
& $\mathrm{P}$ & $7.16 \mathrm{~b}$ \\
\hline 10 & $\mathrm{C}$ & $36.33 \mathrm{a}$ \\
\end{tabular}

Raw data (percentage of incidence) provided but significance was determined by ANOVA using transformed data. Within trials and columns, values followed by the same letter were not significantly different at $\mathrm{P} \leq 0.05$.

Table 3. Cracking incidence (\%) in trees subjected to different timing of treatment applications in trials 6 and 7 .

Çizelge 3.6 ve 7 numaralı çalışmalarda uygulama zamanı farklı olan ağaçlarda çatlama indeksi (\%).

\begin{tabular}{lcc}
\hline Trial & Timining & Cracking(\%) \\
\hline \multirow{4}{*}{6} & $\mathrm{C}$ & $13.60 \mathrm{a}$ \\
& $T 1$ & $10.75 \mathrm{~b}$ \\
& $T 2$ & $8.66 \mathrm{~b}$ \\
& $T 3$ & $7.16 \mathrm{~b}$ \\
7 & $T 4$ & $6.03 \mathrm{~b}$ \\
\hline
\end{tabular}

A significant $(P \leq 0.05)$ impact of treatment on cracking incidence was found in trial 7.No interactions between treatment type (SureSeal (SS) or Parka (P)) and timing of spray application $(T 1, T 2, T 3, T 4)$ was noted in either trial 6 or 7 . In both trials there was no significant difference in treatment type. Raw data (percentage of incidence) provided in table, but significance was determined by 2 -way ANOVA using transformed data. Within trials and columns, values followed by the same letter were not significantly different at $\mathrm{P} \leq 0.05$. 


\section{Impact of Sprays on Quality at Harvest}

Sprays consistently had minimal effect on fruit quality overall; some small improvements were seen. Trials 3 , 5 , and 9 produced fruit that showed no significant difference in any of the quality parameters measured. Trials 4 , and 10 recorded improved quality parameters in fruit from sprayed trees. In trial 4 spray applications increased both size and firmness of fruit and TSS too (Table 4). Trial 10 showed improvements in all quality parameters (Table 5). Trials 1,2 and 8 showed fruit with less sugar at harvest after spray application, and in trials 1 and 2 only decrease significant in firmness (Tables 4 and 5) although values were still above those favourable for export.

Table 4. Fruit quality parameters for fruit at harvest from treated (SS) and untreated control (C) trees from trials 1-5. Çizelge 4. 1-5 denemelerinde SureSeal uygulanmış ve uygulanmamış kontrol ağaçlarında hasatta meyve kalite parametreleri.

\begin{tabular}{lcccc}
\hline Trial & Treatment & $\begin{array}{c}\text { TSS } \\
\left({ }^{\circ} \text { brix }\right) \mathbf{~}\end{array}$ & $\begin{array}{c}\text { Width } \\
(\mathbf{m m})\end{array}$ & $\begin{array}{c}\text { Firmness } \\
\left(\mathbf{m m} \mathbf{g}^{-1}\right)\end{array}$ \\
\hline 1 & $\mathrm{C}$ & $13.22 \mathrm{a}$ & $26.08 \mathrm{a}$ & $340.5 \mathrm{a}$ \\
& $\mathrm{SS}$ & $12.34 \mathrm{a}$ & $25.81 \mathrm{a}$ & $325.1 \mathrm{~b}$ \\
\hline 2 & $\mathrm{C}$ & $18.59 \mathrm{a}$ & $25.58 \mathrm{a}$ & $350.6 \mathrm{a}$ \\
& SS & $16.87 \mathrm{~b}$ & $25.97 \mathrm{a}$ & $332.3 \mathrm{~b}$ \\
\hline 3 & $\mathrm{C}$ & $15.83 \mathrm{a}$ & $29.64 \mathrm{a}$ & - \\
& SS & $16.40 \mathrm{a}$ & $29.13 \mathrm{a}$ & - \\
\hline 4 & $\mathrm{C}$ & $16.98 \mathrm{~b}$ & $25.46 \mathrm{~b}$ & $400.8 \mathrm{~b}$ \\
& SS & $18.70 \mathrm{a}$ & $27.50 \mathrm{a}$ & $482.1 \mathrm{a}$ \\
\hline 5 & $\mathrm{C}$ & $21.04 \mathrm{a}$ & $28.70 \mathrm{a}$ & $458.9 \mathrm{a}$ \\
& SS & $21.99 \mathrm{a}$ & $29.45 \mathrm{a}$ & $442.9 \mathrm{a}$ \\
\hline
\end{tabular}

Within trials and columns, values followed by the same letter were not significantly different at $P \leq 0.05$

Table 5. Fruit quality parameters for fruit at harvest from treated $(P)$ and untreated control $(C)$ trees from trials 8-10. Çizelge 5. 8-10 denemelerinden elde edilen Parka uygulanmış ve uygulanmamış kontrol ağaçlarından hasatta meyve kalite parametreleri.

\begin{tabular}{lcccc}
\hline Trial & Treatment & $\begin{array}{c}\text { TSS } \\
\left({ }^{\circ} \text { brix }\right)\end{array}$ & $\begin{array}{c}\text { Width } \\
(\mathbf{m m})\end{array}$ & $\begin{array}{c}\text { Firmness } \\
\left(\mathbf{m m} \mathbf{~ g}^{-\mathbf{1}}\right)\end{array}$ \\
\hline 8 & $\mathrm{C}$ & $13.48 \mathrm{a}$ & $28.57 \mathrm{a}$ & $12.74 \mathrm{a}$ \\
& $\mathrm{P}$ & $11.48 \mathrm{~b}$ & $29.65 \mathrm{a}$ & $12.12 \mathrm{a}$ \\
\hline 9 & $\mathrm{C}$ & $14.73 \mathrm{a}$ & $28.31 \mathrm{a}$ & $11.71 \mathrm{a}$ \\
& $\mathrm{P}$ & $13.86 \mathrm{a}$ & $27.60 \mathrm{a}$ & $12.54 \mathrm{a}$ \\
\hline 10 & $\mathrm{C}$ & $10.90 \mathrm{~b}$ & $25.26 \mathrm{~b}$ & $12.16 \mathrm{~b}$ \\
& $\mathrm{P}$ & $12.81 \mathrm{a}$ & $32.03 \mathrm{a}$ & $13.40 \mathrm{a}$ \\
\hline
\end{tabular}

Within trials and columns, values followed by the same letter were not significantly different at $P \leq 0.05$.

\section{Impact of Sprays on Post-Harvest Quality}

Assessments of fruit post-harvest highlighted that all fruit, treated and untreated, exhibited similar behaviour during storage; many of the significant differences seen in fruit at harvest were still apparent 2 weeks after storage (Tables 6-8). Trials 3, 8 and 9 again showed fruit with no significant differences in quality parameters between treatments at 2 weeks post-harvest. Fruit from trials 1 and 2 showed the same pattern as at harvest (significant decreases in sugars and firmness with treatment) while the decrease in fruit sugars seen in trial 8 was not seen after storage. Control fruit in trial 5 decreased in size more than treated fruit during storage and resulted in a significantly smaller fruit at postharvest than at harvest. In trial 4, fruit from trees sprayed preharvest were significantly higher in size and sugars than control fruit. A large drop in sugars during storage was noticed in trial 4 in fruit from untreated trees compared to treated trees ( 3 degrees brix compared to 0.3). While results postharvest mirrored those at harvest in trial 7 differed slightly. Trial 7 showed that there was no significant difference in the type of spray application (SS and P) treatment at either harvest or post-harvest, but in trial 7 there was a significant impact of treatment on fruit quality. Application at 10 days post straw colour (T4) simultaneously showed increased size and reduced firmness in fruit post-harvest (Table 7). In general, fruit parameters showed small and insignificant changes over the 2 week storage period (i.e. about $1 \mathrm{~mm}$ and 0.5 degrees brix for size and sugars respectively) across treatments and in trials 1, 2, 4, 5 and 10 changes were significant. Trial 5 was extended to include assessment at 28 days post-harvest storage, this showed continued slow rate of degradation in fruit from both treated and untreated trees (Figure 3). 
Measham et al., The Efficacy of Anti-Transpirant Sprays on Fruit Cracking and on Fruit Quality at Harvest and Post-Harvest Storage in Sweet Cherry

Table 6. Fruit quality parameters after 2 weeks post-harvest storage for fruit from treated (SS) and untreated control (C) trees from trials 1-5.

Çizelge 6. 1-5 denemelerinden SureSeal uygulanmış ve uygulanmamış kontrol ağaçlarında elde edilen meyvelerde 2 hafta depolamadan sonra meyve kalite parametreleri.

\begin{tabular}{|c|c|c|c|c|}
\hline Trial & Treatment & $\begin{array}{c}\text { TSS } \\
\left({ }^{\circ} \text { brix }\right)\end{array}$ & $\begin{array}{l}\text { Width } \\
(\mathrm{mm})\end{array}$ & $\begin{array}{l}\text { Firmness } \\
\left(\mathrm{mm} \mathrm{g}^{-1}\right)\end{array}$ \\
\hline \multirow[t]{2}{*}{1} & $C$ & $13.59 \mathrm{a}$ & $25.16 \mathrm{a}$ & 346.7 a \\
\hline & SS & $12.04 \mathrm{~b}$ & 25.39 a & $331.2 \mathrm{~b}$ \\
\hline \multirow[t]{2}{*}{2} & $C$ & $18.09 \mathrm{a}$ & $25.04 \mathrm{a}$ & $352.3 \mathrm{a}$ \\
\hline & SS & $16.43 \mathrm{~b}$ & $25.10 \mathrm{a}$ & $334.4 \mathrm{~b}$ \\
\hline \multirow[t]{2}{*}{3} & $C$ & $15.42 \mathrm{a}$ & $28.74 \mathrm{a}$ & - \\
\hline & SS & 16.58 a & $29.12 \mathrm{a}$ & - \\
\hline \multirow[t]{2}{*}{4} & C & $13.71 \mathrm{~b}$ & $24.65 b$ & 392.7 a \\
\hline & SS & $18.44 \mathrm{a}$ & $26.62 \mathrm{a}$ & $448.1 \mathrm{a}$ \\
\hline \multirow[t]{2}{*}{5} & C & $19.90 \mathrm{a}$ & $27.73 \mathrm{~b}$ & $466.5 \mathrm{a}$ \\
\hline & SS & $22.33 a$ & $29.33 a$ & $449.4 \mathrm{a}$ \\
\hline
\end{tabular}

* Within trials and columns, values followed by the same letter were not significantly different at $\mathrm{P} \leq 0.05$.

Table 7. Fruit quality parameters after 2 weeks post-harvest storage for fruit from trees subjected to different timing of treatment applications in trial 7

Çizelge 7. Deneme 7'de farklı uygulma zamanlamasına tabi ağaçlardan elde edilen meyvelerde hasat sonrası depolamadan 2 hafta sonra meyve kalite parametreleri.

\begin{tabular}{lcccc}
\hline Trial & Timing & $\begin{array}{c}\text { TSS } \\
\left({ }^{\circ} \text { brix }\right)\end{array}$ & $\begin{array}{c}\text { Width } \\
(\mathbf{m m})\end{array}$ & $\begin{array}{c}\text { Firmness } \\
\left(\mathbf{m m} \mathbf{g}^{-1}\right)\end{array}$ \\
\hline & $\mathrm{C}$ & $16.71 \mathrm{a}$ & $25.17 \mathrm{~b}$ & $447.16 \mathrm{a}$ \\
& $\mathrm{T} 1$ & $16.53 \mathrm{a}$ & $25.85 \mathrm{~b}$ & $424.20 \mathrm{a}$ \\
7 & $\mathrm{~T} 2$ & $16.80 \mathrm{a}$ & $25.87 \mathrm{~b}$ & $436.50 \mathrm{a}$ \\
& $\mathrm{T} 3$ & $16.23 \mathrm{a}$ & $25.70 \mathrm{~b}$ & $429.48 \mathrm{a}$ \\
\hline
\end{tabular}

The effect of treatment type (SureSeal (SS) or Parka (P)) was not significant; the timing of spray application (T1, T2, T3, T4) showed differences in fruit size, and firmness. Values followed by the same letter were not significantly different at $\mathrm{P} \leq 0.05$.

Table 8. Fruit quality parameters after 2 weeks post-harvest storage for fruit from treated (SS) and untreated control (C) trees from trials $1-5$.

Çizelge 8. 1-5 denemelerinden SureSeal uygulanmış ve uygulanmamış kontrol ağaçlarında elde edilen meyvelerde 2 hafta depolamda sonra meyve kalite parametreleri.

\begin{tabular}{ccccc}
\hline Trial & Treatment & $\begin{array}{c}\text { TSS } \\
\left({ }^{\circ} \text { brix }\right)\end{array}$ & $\begin{array}{c}\text { Width } \\
(\mathbf{m m})\end{array}$ & $\begin{array}{l}\text { Firmness } \\
(\mathbf{N})\end{array}$ \\
\hline 8 & $\mathrm{C}$ & $14.20 \mathrm{a}$ & $28.59 \mathrm{a}$ & $13.22 \mathrm{a}$ \\
& $\mathrm{P}$ & $14.48 \mathrm{a}$ & $28.62 \mathrm{a}$ & $12.50 \mathrm{a}$ \\
\hline 9 & $\mathrm{C}$ & $14.53 \mathrm{a}$ & $27.85 \mathrm{a}$ & $11.50 \mathrm{a}$ \\
& $\mathrm{P}$ & $14.85 \mathrm{a}$ & $27.42 \mathrm{a}$ & $12.38 \mathrm{a}$ \\
\hline 10 & $\mathrm{C}$ & $13.70 \mathrm{a}$ & $30.14 \mathrm{~b}$ & $12.69 \mathrm{a}$ \\
& $\mathrm{P}$ & $14.15 \mathrm{a}$ & $31.81 \mathrm{~b}$ & $13.78 \mathrm{a}$ \\
\hline
\end{tabular}

* Within trials and columns, values followed by the same letter were not significantly different at $P \leq 0.05$. 

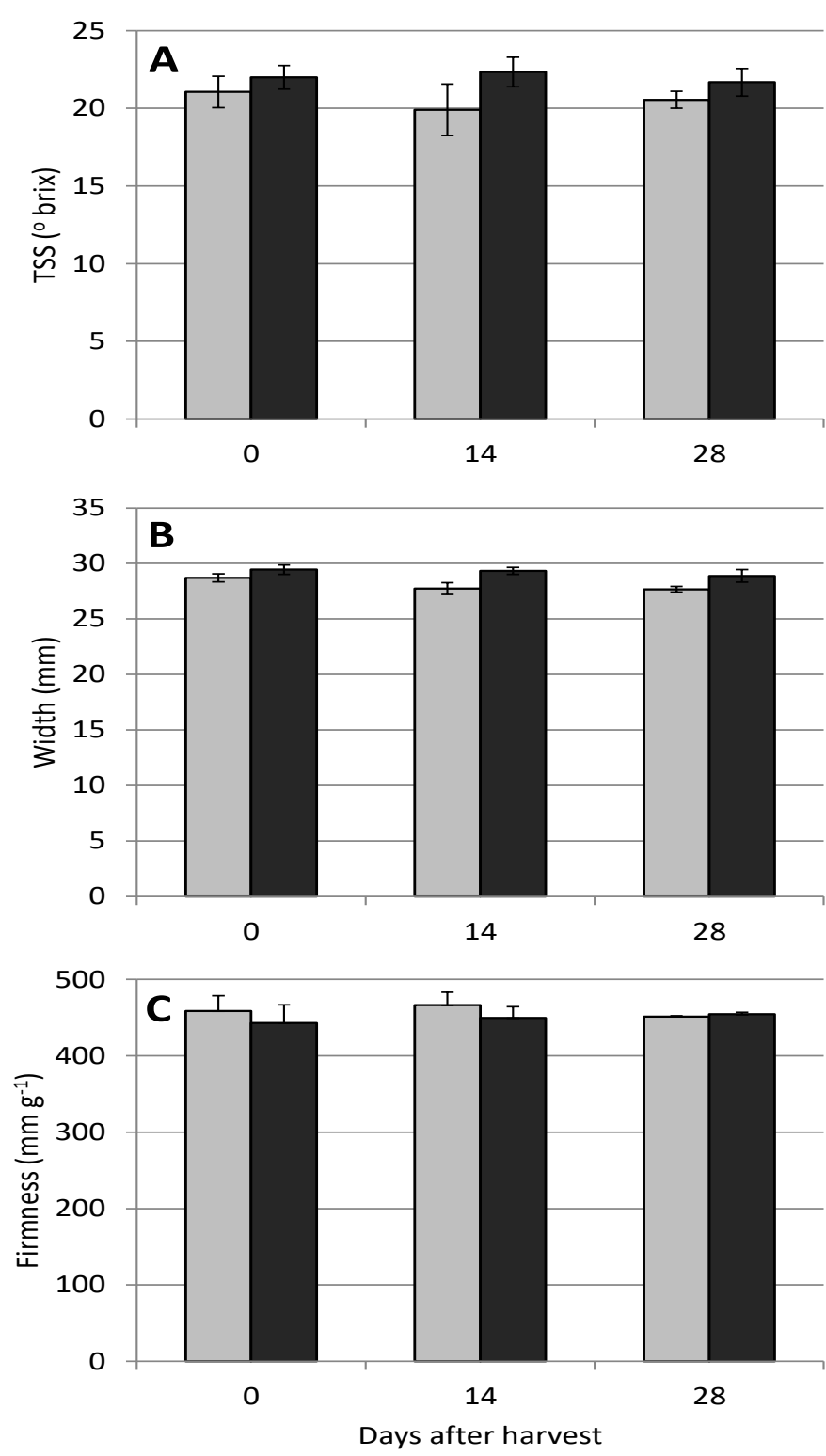

Figure 3. Fruit sugars (A), size (B) and firmness (C) in fruit from treated (SS; light bars) and untreated control (C; dark bars) trees at harvest ( 0 days) and after 14 and 28 days of storage post-harvest (trial 5 ).

Şekil 3. Hasat (O gün) ve hasattan 14 ve 28 gün sonra depolamada Sureseal uygulanmış (açık renkli sütunlar) ve kontrol (C; koyu renkli sütunlar) ağaçlarından elde edilen meyvelerdeki şeker (A), büyüklük (B) ve meyve eti sertliği (C) hasat sonrası depolama (deneme 5).

Error bars represent the standard error of the mean.

\section{DISCUSSION}

This study was designed not just to confirm the efficacy of anti-transpirant sprays on reducing fruit cracking in cherry, but to evaluate the impact on fruit quality at harvest and during post-harvest storage. We have shown that fruit cracking can be significantly reduced without loss of quality at harvest, or after post-harvest storage (except trials 1 and 2). Furthermore, this study provides a higher level of confidence in using pre-harvest sprays such as SureSeal and Parka than has previously been determined. The significantly higher yields resulting from the use of both SureSeal and Parka consisted of fruit of high quality, which performed well post-harvest and was capable of meeting market expectations. We have demonstrated that increasing marketable period of sweet cherry fruit through reduced damage with pre-harvest applications is possible, and that fruit quality at post-harvest is maintained.

Given there was no significant difference in the impact on cracking incidence or fruit quality of the 2 spray types (SureSeal and Parka) assessed in this study, we will discuss results in the context of the sprays being the same. Reduction in rain-induced cracking damage of fruit was significant in all trials; a $20 \%$ reduction was seen even with rainfall amounts of up to $86 \mathrm{~mm}$ in the weeks preceding harvest in trial 10. Trial 5 saw a reduction in 
cracking of $53 \%$ with $53 \mathrm{~mm}$ of rain. Rainfall amount was not related to cracking incidence, in accordance with Measham et al. (2009) that quantified cracking and rainfall over several years and varieties, and with Nielsen et al. (2014) that reported different cracking levels with similar rainfall amounts. There are now a growing number of studies (Lane, 2000; Measham et al., 2009; Measham et al., 2012; Nielsen et al., 2014) that support a strong environmental as well as an anatomical influence on susceptibility. In this study, spray applications resulted in significant reductions in end-cracks but not side cracks, supporting the notion that these crack types are generated by water uptake across the skin (Measham et al., 2010). It further supports the idea that resilience can be built into the fruit prior to rainfall events through spray applications and it follows then that fruit skin properties are critical in response to environment, and that anatomical features can be more easily manipulated than environment. It is worthwhile nothing that in this study, high reductions in cracking $(77 \%$ and $53 \%$ in trials 9 and 5 respectively) were noted with high levels of rainfall. Thus, as a strategy to build resilience in fruit (particularly through skin covering that prevents water uptake) these sprays offer benefit.

Adequate skin and cuticle integrity and skin elasticity are also important for optimal quality of fruit at harvest and during storage. Preventing water loss from fruit is equally important in maintaining quality as water uptake. Loss of water will impact on fruit size which is a key indicator of economic value (Zhang and Whiting, 2011; Puniran et al., 2013), and can be rapidly lost during both the harvest process and during post-harvest storage. It has been determined that the acceptable weight loss from orchard to consumer is only $5 \%$. This study highlights that water loss from fruit was not enhanced pre-harvest with spray applications; fruit size was not significantly different, and in 2 trials ( 4 and 10 ) size was actually greater with spray treatment (as would be expected given the anti-transpirant nature of the product). Indeed, this anti-transpirant effect seems to have remained during storage in one trial (trial 5) which showed a greater loss in size in treated fruit after storage compared to untreated. Water loss is a critical factor in postharvest management of cherry fruit during storage given that cherry fruit have a relatively thin skin and higher water conductance than other fruit. Thus having a potential new option for water loss post-harvest in addition to managing temperature and relative humidity would be beneficial, and warrants research into the use of anti-transpirants post-harvest. Hu et al (2011) proposes that the addition of coatings help maintain firmness in fruit due to decreased water loss. Cherry fruit have been shown to become firmer during storage in other studies (Mozetic, 2006; Bound et al., 2013). This study also showed fruit which increased in firmness over time, albeit only slightly, in all but 2 trials. Loss of firmness, however, can also result from other physiological actions such as degradation of cell walls (Sekse, 2008) in addition to water loss. In one trial (trial 4) there was a greater loss of sugars during storage in control fruit compared to treated fruit. It is possible that in this trial, greater respiration was promoted via a less complete fruit covering. Greater respiration can also be associated with a higher incidence of decay organisms; this was not assessed in this study but in field observations noted a higher than usual disease incidence at harvest, rainfall was higher than usual (monthly average is $27 \mathrm{~mm}$ ). Again, there is the potential to expand research regarding pre-harvest spray management to improve the understanding of the impact of coating on disease prevention during cherry fruit storage.

However, the results of this study showed that edible coating materials applied to reduce the rain-induced cracking can be used to maintain fruit quality in storage. We provide evidence that of the continued benefit of pre-harvest treatment post-harvest. Future investigation should target postharvest water transpiration patterns (Measham et al., 2012) and possible treatment for in-line cracking, and post-harvest cracking.

\section{CONCLUSIONS}

The use of both SureSeal and Parka improved the yield of marketable cherry fruit (except trials 1 and 2). Reduced cracking was achieved, with negligible impact on fruit quality at harvest, or after storage. This highlights the use of such sprays as a viable management technique for achieving a more consistent supply of high quality fruit, and reduces the risk of variable climates. It also exposes the potential for these products to be an alternative to other post-harvest chemical treatments for storage problems such as water loss and fungal decay.

\section{CONFLICT OF INTEREST}

The authors declare that they have no conflict of interest. 


\section{DECLARATION OF AUTHOR CONTRIBUTION}

Penny Measham Lynn Edwards Long, Erdal Aglar and Clive Kaiser Planning, design, analysis of fruit and data analysis of experiment, and writing of the manuscript.

\section{REFERENCES}

Alkio, M., Jonas U., Sprink, T., Van Nocker, S., \& Knoche, M. (2012). Identification of putative candidate genes involved in cuticle formation in Prunus avium (sweet cherry) fruit. Annals of Botany, 110, 101-112.

Bound, S. A., Close, D. C., Quentin, A. G., Measham, P. F., \& Whiting, M. D. (2013). Crop load and time of thinning interact to affect fruit quality in sweet cherry. Journal of Agricultural Science (Toronto), 5, 216-230.

Clayton, M., Biasi, W. V., Agar, I. T., Southwick, S. M., \& Mitcham, E. J. (2003). Postharvest quality of 'Bing' cherries following preharvest treatment with hydrogen cyanamide, calcium ammonium nitrate, or gibberellic acid. HortScience, 38, 407-411.

Hanson, E. J., \& Proebsting, E. L. (1996). Cherry nutrient requirements and water relations. In A. D. Webster, N. E. Looney (Eds.), Cherries: Crop Physiology, Production and Uses. (pp. 243-258).CAB International.

Hovland, K. L., \& Sekse, L. (2004). Water uptake through sweet cherry (Prunus avium L.) fruit pedicels in relation to fruit development. Acta Agriculturae Scandinavica Section B-Soil and Plant Science, 54, 264-266.

Hu, H. G., Li, X. P., Dong, C., \& Chen, W. X. (2011). Effects of wax treatment on quality and postharvest physiology of pineapple fruit in cold storage. African Journal of Biotechnology, 10, 7592-7603.

Ikediala, J. N., Hansen, J. D., Tang, J., Drake, S. R., \& Wang, S. (2002). Development of a saline water immersion technique with RF energy as a postharvest treatment against codling moth in cherries. Postharvest Biology and Technology, 24, 2537.

Kaiser, C., Fallahi, E., Meland, M., Long, L. E., \& Christensen, J. M. (2014). Prevention of sweet cherry fruit cracking using sureseal, an organic biofilm. Acta Horticulture, 1020, 477-488.

Knoche, M., Beyer, M., Peschel, S., Oparlakov, B., Bukovac, M. J. (2004). Changes in strain and deposition of cuticle in developing sweet cherry fruit. Physiologia Plantarum, 120, 667-677.

Knoche, M., \& Peschel, S. (2001). Water on the surface aggravates microscopic cracking of the sweet cherry fruit cuticle. Journal of the American Society for Horticultural Science, 131, 192-200.

Knoche, M., Peschel, S., Hinz, M., \& Bukovac, M. J. (2001). Studies on water transport through the sweet cherry fruit surface: II. Conductance of the cuticle in relation to fruit development. Planta, 213, 927-936.

Lane, W. D., Meheriuk, M., \& McKenzie, D. L. (2000). Fruit cracking of a susceptible, an intermediate, and a resistant sweet cherry fruit cultivar. HortScience, 35, 239-242.

Liu, Y. H., Offler, C. E., \& Ruan, Y. L. (2013). Regulation of fruit and seed response to heat and drought by sugars as nutrients and signals. Frontiers in Plant Science, 4, 1-12.

Long, L. E., Kaıser, C., Christensen, J. M., Hanrahan, I., Meland, M., \& Fallahi, E. (2009). Prevention of sweet cherry fruit cracking using SureSeal, an organic biofilm. Proceedings of the Sixth International Cherry Symposium. Reñaca, Chile.

Measham, P. F., Bound, S. A., Gracie, A. J., \& Wilson, S. J. (2009). Incidence and type of cracking in sweet cherry (Prunus avium L.) are affected by genotype and season. Crop and Pasture Science, 60, 1002-1008.

Measham, P. F., Bound, S. A., Gracie, A. J., \& Wilson, S. J. (2012). Crop load manipulation and fruit cracking in sweet cherry (Prunus avium L.). Advances in Horticultural Science, 26, 25-31.

Measham, P. F., Gracie, A. J. Wilson, S. J., \& Bound, S. A. (2010). Vascular flow of water induces side cracking in sweet cherry (Prunus avium L.). Advances in Horticultural Science, 24, 243-248.

Mozetic, B., Simcic, M., \& Trebse, P. (2006). Anthocyanins and hydroxycinnamic acids of Lambert Compact cherries (Prunus avium L.) after cold storage and 1-methylcyclopropene treatment. Food Chemistry, 97, 302-309.

Nielsen, U. N., Ayres, E., Wall, D. H., Li, G., Bardgett, R. D., Wu, T., \& Garey, J. R. (2014). Global- scale pattern of assemblage structure of soil nematodes in relation to climate and ecosystem properties. Global Ecology and Biogeography, 23(2014), 968-978.

Puniran, N., Close, D. C., Bound, S. A., Corkrey, R., \& Whiting, M. D. (2012). Fruit colour, size and temperature affect the shelf life of sweet cherry. Acta Horticulturae, 934, 995-1002.

Sekse, L. (1995). Fruit cracking in sweet cherries (Prunus avium L.). Some physiological aspects-a mini review. Scientia Horticulturae, 63, 135-141. 
Measham et al., The Efficacy of Anti-Transpirant Sprays on Fruit Cracking and on Fruit Quality at Harvest and Post-Harvest Storage in Sweet Cherry

Sekse, L. (2008). Fruit cracking in sweet cherries-some recent advances. V. International Cherry Symposium, Acta Horticulture.

Simon, G. (2006). Review on rain induced fruit cracking of sweet cherries (Prunus avium L.), its causes and the possibilities of prevention. International Journal of Horticultural Science, 12, 27-35.

Torres, C. A., Yuri, J. A., Venegas, A., \& Lepe, V. (2009). Use of a lipophilic coating pre-harvest to reduce sweet cherry (Prunus avium L.) rain-cracking. VI. International Cherry Symposium, Renaca, Chile.

Wang, Y., \& Long, L. E. (2014). Respiration and quality responses of sweet cherry to different atmospheres during cold storage and shipping. Postharvest Biology and Technology, 92, 62-69.

Webster, A. D., \& Cline, J. A. (1994). All about cherry cracking. Tree Fruit Leader, 3(2).

Zhang, C., \& Whiting, M. D. (2011). Improving 'Bing' sweet cherry fruit quality with plant growth regulators. Scientia Horticulturae, 127, 341-346. 